\title{
Changes in physical and chemical characteristics of fermented cocoa (Theobroma cacao) beans with manual and semi-mechanized transfer, between fermentation boxes
}

\author{
Cambios en la características físicas y químicas de granos de cacao (Theobroma \\ cacao) fermentados con transferencia manual y semi-mecanizada, entre las cajas \\ de fermentación \\ Pedro. P. Peláez ${ }^{1, ~}$; Saulo Guerra ${ }^{1}$; David Contreras ${ }^{2}$ \\ ${ }^{1}$ Department of Science, Technology, and Food Engineering, National Agrarian University of the Jungle, Tingo Maria, \\ Hиánuco, Peru \\ 2 ACOPAGRO Agricultural Cooperative Cacaotera, Juanjui, Tarapoto, Peru.
}

Received May 01, 2016. Accepted Jun 30, 2016.

\begin{abstract}
The aim of this study was to evaluate variation in the physical and chemical properties of fermented cocoa beans with cocoa beans transfer between wooden fermentation boxes manually (M) and semi-mechanized (SM) way. Mass temperature, moisture, $\mathrm{pH}$, and total acidity of the cotyledon and pulp; the total polyphenol, anthocyanin, reducing sugar, theobromine, and caffeine content in fresh, fermented, and dried beans; and percentage of fermented beans and time required to move beans during fermentation were determined. The cocoa used grew in the Pachiza district of the San Martin region of Peru. Cocoa sampling was each 0, 48, 72, $96,120,144$, and $168 \mathrm{~h}$ of fermentation. The cocoa mass temperature was highest with both removal systems after $96 \mathrm{~h}$ of fermentation. M cotyledon and pulp samples had the highest moisture content and titratable acidity, while cotyledon and pulp $\mathrm{pH}$ with both systems were statistically equal. In contrast, fermented beans had a higher polyphenol, anthocyanin, reducing sugar, theobromine, and caffeine content with SM. SM produced the greatest amount of fermentation (91.67\%) and required the shortest amount of time to move beans (78.56 min). In conclusion, the system of fermentation of cocoa beans with SM was faster and produced fermented grains with high chemical quality.
\end{abstract}

Keywords: Fermented cocoa, transfer, manually, semi-mechanized.

\section{Introduction}

Cocoa postharvest handling is very important and determines the quality of the product on the market (Sandhya et al., 2016). Fermentation of cocoa beans is the first step in the chocolate-making chain (De Melo Pereira et al., 2013). Cocoa bean fermentation is very important and beneficial; microbial fermentation of cocoa removes mucilage (Hatmi et al., 2015) and induces a set of internal biochemical reactions in the cotyledon that lead to modification of the chemical composition of cocoa beans and the formation of aromatic precursors. During fermentation, the microbial succession occurs by changes in temperature, $\mathrm{pH}$ and

* Corresponding author

E-mail: pedro.pelaez@unas.edu.pe (P.P. Peláez). availability of oxygen (Kongor et al., 2016). As the aeration increases due to further cocoa pulp drainage and the temperature of the fermenting cocoa pulpbean mass increases above $37{ }^{\circ} \mathrm{C}$. The environmental conditions become favorable for the growth of acetic acid bacteria, which oxidize the ethanol produced by yeasts and lactic acid produced by lactic acid bacteria into acetic acid and subsequently overoxidize this acetic acid into carbon dioxide and water (Illeghems et al., 2015). Hence, when and how fast the cocoa mass is turned up is important for achieving the desired amount of acetic acid fermentation; improper removal promotes lactic acid fermentation DOI: 10.17268/sci.agropecu.2016.02.04 
which ultimately affects the quality of commercial cocoa (Afoakwa et al., 2011). In order to determine the effect of manually (M) and semi-mechanized (SM) of cocoa beans transfer during fermentation, we evaluated the temperature, moisture content, $\mathrm{pH}$, and total acidity in the cotyledon and pulp, as well as quantified the total polyphenol, anthocyanin, reducing sugar, theobromine, and caffeine content in fresh, fermented, and dried cocoa beans. The aim of this study was to evaluate variation in the physical and chemical properties of cocoa bean fermentation with cocoa beans transfer manually (M) and semimechanized (SM) way in order to improve the conditions in the processing.

\section{Materials and methods}

\subsection{Raw material}

Cocoa beans: This research used Forastero hybrid and CCN-51 cocoa beans from the Pachiza district of Mariscal Caceres province in the San Martin region of Peru. Beans were grown at an altitude of $328 \mathrm{~m}$ to $07^{\circ} 17^{\prime} 49^{\prime \prime}$ south latitude and $76^{\circ}$ 46 '17" north latitude. Farmers harvest cacao pods, break pods, get the mucilage along with grains. The local fermentation uses wooden boxes of $1 \mathrm{~m}^{3}$ capacity, standing cocoa beans in the box, where a spontaneous fermentation occurs with 500 $\mathrm{kg}$, for $168 \mathrm{~h}$ at room temperature. Cocoa beans were transferred manual and semimechanized way, from one box to another, once per day, after the second day to obtain a uniform fermentation.

\subsection{Analytical procedures Temperature}

The temperature measurements in the cocoa mass was in the center and on the environment, performed after $0,48,72,96$, 120,144 , and $168 \mathrm{~h}$ of fermentation.

\section{pH}

$\mathrm{pH}$ of the cocoa pulp and cotyledons were determined using a $\mathrm{pH}$ meter after 0,48 , $72,96,120,144$, and $168 \mathrm{~h}$ of fermentation according to Method 931.04 (AOAC, 1995).
Acidity: Total titratable acidity as acetic acid (g/100 g cocoa), in the cocoa pulp and cotyledons, was determined after $0,48,72$, 96, 120, 144, and $168 \mathrm{~h}$ of fermentation using Method 942.15 (AOAC, 1995).

\section{Moisture}

Total moisture content (\%) in the cocoa mass and surrounding environment was determined after $0,48,72,96,120,144$, and $168 \mathrm{~h}$ of fermentation using Method 931.04 (AOAC, 1995).

\section{Polyphenols}

Total polyphenol content was quantified using the Folin-Ciocalteu method in cocoa bean extracts after $0,48,72,96,120,144$, and $168 \mathrm{~h}$ of fermentation; results were expressed in gallic acid equivalents $[\mathrm{mg}$ GAE/g extract] (Symonowicz et al., 2012; Sultana et al., 2012).

\section{Anthocyanins}

Total anthocyanin content (mg cyanidin-3glucoside/g cocoa) was measured by the $\mathrm{pH}$ differential method described by Symonowicz et al. (2012) after 0, 48, 72, $96,120,144$, and $168 \mathrm{~h}$ of fermentation.

\section{Reducing sugars}

Total amount of unfermented (reducing) sugar (\%) in cocoa beans was determined using dinitrosalicylic acid and quantified (mg sugar/g cocoa) from a standard curve plotted based on the absorbance at $510 \mathrm{~nm}$ (Miller, 1959) after 0, 48, 72, 96, 120, 144, and $168 \mathrm{~h}$ of fermentation.

\section{Theobromine and caffeine}

Analysis of total theobromine ( $\mathrm{g}$ theobromine/g cocoa) and caffeine ( $\mathrm{g}$ caffeine/g cocoa) content used a Shimadzu LC-10AT reverse-phase liquid chromatograph (VP Scientific, Columbia, MD 21046, U.S.A.). Consisting of a Shimadzu DGU-14A degasser, manual Rheodyne 7725i injector, management pack solvent with Shimadzu LC-10AT quaternary pump, Shimadzu CTO-10AS single-column oven, and Shimadzu UVVis SPD-10AV detector. A Shimadzu SCL-10AV interface to determine chromatographic peak purity, and identification and integration of peaks used Shimadzu CLASS-VP ${ }^{\mathrm{TM}}$ software version 6.13 SP2. Chromatographic separation was 
completed using a C18 Ultra guard cartridge $(20 \mathrm{~mm} \quad \mathrm{x} 4 \mathrm{~mm}$; Code: 917450220; Restek, Bellefonte, PA 16823, United States with a C18 Ultra column $(150 \mathrm{~mm} \times 4.6 \mathrm{~mm} \times 5 \mu \mathrm{m}$; Code: 9174565; Restek, Bellefonte, PA 16823, United States. The column temperature was kept at $35{ }^{\circ} \mathrm{C}$. Detection of theobromine and caffeine in fresh, fermented $(0,48,72,96,120,144$, and 168 $\mathrm{h}$ ), and dry beans with a $7 \%$ moisture content was performed at $210 \mathrm{~nm}$. The mobile phase was a mixture of acetic acid $(0.3 \%)$ and methanol $(85: 15)$ and samples solutions filtered with a nylon microfilter $(0.2 \mu \mathrm{m})$, the flow rate was $1 \mathrm{ml} / \mathrm{min}$, and the sample volume was $20 \mu \mathrm{l}$ (Lo Coco et al., 2007; Menguy et al., 2009). The analysis was conducted in triplicates and the mean values reported.

\section{Cutting test}

This test was conducted to physically evaluate and determine the percentage of good quality, dried, fermented cocoa beans by separating them from defective beans (e.g., purple or partially violet); the sum of the number of fermented and defective beans represented $100 \%$ (National Federation of Cocoa - Cocoa National Fund, 2004).

\section{Experimental design and statistical analysis}

Our study had a completely randomized design and replicated thrice followed by Tukey's test to determine statistical differences using Centurion Statgraphics XV.V.15.2.06 software (De Mendiburu,
2007). A p-value $<0.05$ was considered statistically significant. All values are presented as means $(\mathrm{Me}) \pm$ standard error of the mean (SEM) unless indicated otherwise.

\section{Results and discussion}

\subsection{Cocoa mass and environment temperature}

The highest mean temperature of the cocoa mass $\left(47.7{ }^{\circ} \mathrm{C}\right)$ occurred after $96 \mathrm{~h}$ of fermentation for both M and SM (Table 1). However, cocoa mass temperatures were statistically different $(\mathrm{p} \leq 0.05)$ between the two transfer ways at other time points (Table 1). It reaffirms the results reported by Amores et al. (2009) who suggested that early on in the fermentation process cocoa mass temperatures normally vary between 45 and $50{ }^{\circ} \mathrm{C}$. Schwan (1998) reported that when the cocoa mass temperature raises to about $50{ }^{\circ} \mathrm{C}$, and the heat and acid result in chemical reactions in the beans known as curing, production of organic acids (oxalic, phosphoric, succinic, malic, and acetic acids).

The mean temperature of the cocoa mass at the end of fermentation (168 h) was 45.13 $\pm 2.34{ }^{\circ} \mathrm{C}$ with $\mathrm{SM}$ and $41.90 \pm 0.60{ }^{\circ} \mathrm{C}$ with $\mathrm{M}$. The mean cocoa mass temperature decreased after $96 \mathrm{~h}$ due to inactivation of predominant bacteria at temperatures $>40$ ${ }^{\circ} \mathrm{C}$ and embryonic death caused by acetic acid penetration into the bean, favoring development of chocolate flavor precursors (Kongor et al., 2016).

\section{Table 1}

Mean temperature of the cocoa mass and surrounding environment during fermentation

\begin{tabular}{|c|c|c|c|c|}
\hline \multirow{2}{*}{$\begin{array}{l}\text { Fermentation } \\
\text { time } \\
\text { (h) }\end{array}$} & \multicolumn{2}{|c|}{$\begin{array}{c}\text { Manually Cocoa Beans } \\
\text { Transfer }\end{array}$} & \multicolumn{2}{|c|}{$\begin{array}{l}\text { Semi-mechanized Cocoa Beans } \\
\text { Tansfer }\end{array}$} \\
\hline & $\begin{array}{l}\mathrm{TCM} \\
\left({ }^{\circ} \mathrm{C}\right)\end{array}$ & $\begin{array}{l}\text { ET } \\
\left({ }^{\circ} \mathrm{C}\right)\end{array}$ & $\begin{array}{l}\text { TCM } \\
\left({ }^{\circ} \mathrm{C}\right)\end{array}$ & $\begin{array}{l}\text { ET } \\
\left({ }^{\circ} \mathrm{C}\right)\end{array}$ \\
\hline 0 & $28.30 \pm 0.43^{\mathrm{a}}$ & $28.00 \pm 0.00$ & $29.77 \pm 0.18^{\mathrm{a}}$ & $25.85 \pm 2.15$ \\
\hline 48 & $35.7 \pm 0.09^{\mathrm{ab}}$ & $24.90 \pm 0.10$ & $39.80 \pm 3.60^{b c}$ & $25.50 \pm 0.50$ \\
\hline 72 & $40.23 \pm 0.24^{b c}$ & $25.00 \pm 0.30$ & $44.47 \pm 2.10^{\mathrm{cd}}$ & $26.60 \pm 0.60$ \\
\hline 96 & $47.70 \pm 0.15^{\mathrm{d}}$ & $27.95 \pm 0.45$ & $47.70 \pm 0.12^{\mathrm{d}}$ & $27.40 \pm 3.20$ \\
\hline 120 & $43.67 \pm 0.03^{\mathrm{cd}}$ & $27.90 \pm 1.20$ & $45.47 \pm 0.94^{\mathrm{cd}}$ & $27.75 \pm 1.35$ \\
\hline 144 & $45.03 \pm 0.35^{\mathrm{cd}}$ & $27.10 \pm 0.30$ & $45.73 \pm 0.43^{\mathrm{cd}}$ & $26.50 \pm 0.90$ \\
\hline 168 & $41.90 \pm 0.60^{\mathrm{cd}}$ & $26.05 \pm 0.25$ & $45.13 \pm 2.34^{\mathrm{cd}}$ & $25.75 \pm 0.55$ \\
\hline
\end{tabular}

TCM: Cocoa mass temperature; ET: Environment temperature. Values in the same column with the same superscript letters are statistically equal. Values represent the $\mathrm{Me} \pm \mathrm{SEM} ; \mathrm{n}=3 ; \mathrm{p} \leq 0.05$, Tukey's test. 


\subsection{Moisture variation in cocoa beans over time}

The mean moisture content of cocoa beans was statistically different $(\mathrm{p} \leq 0.05)$ throughout the fermentation process (Figure 1) and may be due to the variety and maturity of the fruit. The highest mean moisture content existed in fresh beans $(0$ h) with both $\mathrm{M}(51.89 \pm 1.74 \%)$ and $\mathrm{SM}$ $(51.91 \pm 0.74 \%)$. After 168 hours of fermentation, the moisture content fell to $46.33 \pm 0.60 \%$ with $M$ and $42.77 \pm 1.90 \%$ with SM ( $p>0.05)$. Similar to these results, Rodriguez et al. (2012) reported $43.7 \%$ moisture in fermented beans. Furthermore, stated that fermentation of cocoa bean pulp by microbial action causes cell rupture and release of intracellular juices, thereby reducing the amount of moisture retained by beans.

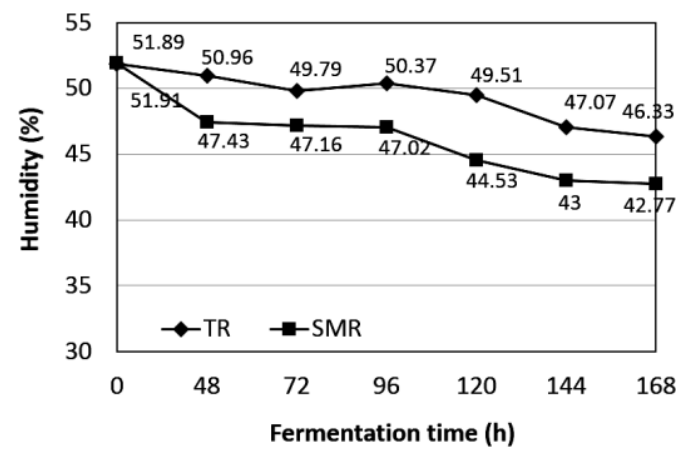

Figure 1. Moisture content in fermented cocoa beans over time with manually $(\mathrm{M})$ and semimechanical (SM) cocoa beans transfer.

Statistical analysis revealed significant differences $(p \leq 0.05)$ between the $\mathrm{pH}$ of the pulp and cotyledon of cocoa beans with both $\mathrm{M}$ and SM throughout the fermen- tation process (Table 2). However, the $\mathrm{pH}$ of the pulp and cotyledon were statistically equal by the end of fermentation (168 h). The $\mathrm{pH}$ of the cotyledon decreased consistently from $6.99 \pm 0.20$ in fresh beans $(0 \mathrm{~h})$ to $4.76 \pm 0.03$ in fully fermented beans ( $168 \mathrm{~h}$ ) with M. Similarly, Graziani de Fariñas et al. (2002) reported a fermented cocoa bean cotyledon $\mathrm{pH}$ of 4.75. Amores et al. (2009) suggested that acetic acid infiltrates the cotyledon and lowers the $\mathrm{pH}$ from 6.4 to 4.5 during fermentation at temperatures $>45{ }^{\circ} \mathrm{C}$. This acidification disintegrates compartments of the cell and eventually leads to cellular death. The cocoa bean pulp is permeable to acetic acid, which then passes into the cotyledon after three days, killing the embryo and lowering the $\mathrm{pH}$ to 4.8 . Furthermore, Afoakwa et al. (2008) postulated that poorly fermented cocoa has a $\mathrm{pH}$ of 5.5-5.8 while properly fermented cocoa has a $\mathrm{pH}$ of 4.7-5.2.

\subsection{Acidity of cocoa bean pulp and cotyledons}

Statistical analysis revealed significant differences $(p \leq 0.05)$ between the total titratable acidity of the pulp and cotyledon of cocoa beans with both $M$ and SM throughout the fermentation process (Table 3). Cotyledon acidity increased to $2.88 \pm$ 0.18 as acetic acid ( $\mathrm{g} / 100 \mathrm{~g}$ cocoa), with $\mathrm{M}$ by the end of fermentation (168 h). Rivera et al. (2012) indicated that acids produced by microorganisms during fermentation cause an increase in acidity and consequent decrease in $\mathrm{pH}$.

Table 2

Variation $\mathrm{pH}$ of cocoa beans during fermentation

\begin{tabular}{cccccc}
\hline \multirow{2}{*}{$\begin{array}{c}\text { Fermentation } \\
\text { time }(\mathrm{h})\end{array}$} & \multicolumn{2}{c}{ Manually Cocoa Beans Transfer } & & \multicolumn{2}{c}{ Semi-mechanized Cocoa Beans Transfer } \\
\cline { 2 - 3 } \cline { 5 - 6 } & Pulp & Cotyledon & & Pulp & Cotyledon \\
\hline 0 & $4.21 \pm 0.02^{\mathrm{a}}$ & $6.99 \pm 0.20^{\mathrm{d}}$ & & $4.20 \pm 0.03^{\mathrm{a}}$ & $7.08 \pm 0.09^{\mathrm{d}}$ \\
78 & $4.39 \pm 0.05^{\mathrm{ab}}$ & $5.98 \pm 0.02^{\mathrm{c}}$ & & $4.50 \pm 0.04^{\mathrm{bc}}$ & $5.87 \pm 0.43^{\mathrm{bc}}$ \\
96 & $4.63 \pm 0.08^{\mathrm{cd}}$ & $5.37 \pm 0.11^{\mathrm{abc}}$ & & $4.67 \pm 0.07^{\text {cde }}$ & $5.07 \pm 0.40^{\mathrm{ab}}$ \\
120 & $4.77 \pm 0.05^{\mathrm{de}}$ & $5.05 \pm 0.03^{\mathrm{ab}}$ & & $4.79 \pm 0.05^{\mathrm{de}}$ & $5.00 \pm 0.02^{\mathrm{ab}}$ \\
144 & $4.80 \pm 0.03^{\mathrm{de}}$ & $4.91 \pm 0.06^{\mathrm{a}}$ & & $4.85 \pm 0.03^{\mathrm{e}}$ & $4.93 \pm 0.02^{\mathrm{a}}$ \\
168 & $4.79 \pm 0.05^{\mathrm{de}}$ & $4.81 \pm 0.02^{\mathrm{a}}$ & & $4.86 \pm 0.02^{\mathrm{e}}$ & $4.86 \pm 0.01^{\mathrm{a}}$ \\
\hline
\end{tabular}

Values in the same column with the same superscript letters are statistically equal. Values represent the Me \pm $\mathrm{SEM} ; \mathrm{n}=3 ; \mathrm{p} \leq 0.05$, Tukey's test. 
Table 3

Variation of acidity of cocoa beans during fermentation

\begin{tabular}{cccccc}
\hline $\begin{array}{c}\text { Fermentation } \\
\text { time }(\mathrm{h})\end{array}$ & \multicolumn{2}{c}{ Manually Cocoa Beans Transfer } & & \multicolumn{2}{c}{ Semi-mechanized Cocoa Beans Transfer } \\
\cline { 2 - 3 } \cline { 5 - 6 } & Pulp & Cotyledon & & Pulp & Cotyledon \\
\hline 0 & $0.96 \pm 0.19^{\mathrm{ab}}$ & $0.77 \pm 0.19^{\mathrm{a}}$ & & $0.77 \pm 0.19^{\mathrm{a}}$ & $0.58 \pm 0.00^{\mathrm{a}}$ \\
78 & $1.44 \pm 0.18^{\mathrm{bc}}$ & $1.08 \pm 0.00^{\mathrm{ab}}$ & & $1.62 \pm 0.00^{\mathrm{bcd}}$ & $1.08 \pm 0.00^{\mathrm{ab}}$ \\
96 & $1.98 \pm 0.18^{\mathrm{cde}}$ & $1.62 \pm 0.00^{\mathrm{bc}}$ & & $2.16 \pm 0.00^{\mathrm{def}}$ & $1.62 \pm 0.00^{\mathrm{bc}}$ \\
120 & $2.16 \pm 0.00^{\mathrm{def}}$ & $1.98 \pm 0.18^{\mathrm{cd}}$ & & $2.16 \pm 0.00^{\mathrm{def}}$ & $2.16 \pm 0.00^{\text {cde }}$ \\
144 & $2.52 \pm 0.18^{\mathrm{efg}}$ & $2.16 \pm 0.00^{\text {cde }}$ & & $2.52 \pm 0.18^{\mathrm{efg}}$ & $2.34 \pm 0.18^{\text {cde }}$ \\
168 & $2.70 \pm 0.00^{\mathrm{fg}}$ & $2.52 \pm 0.18^{\mathrm{de}}$ & & $2.70 \pm 0.00^{\mathrm{fg}}$ & $2.16 \pm 0.31^{\text {cde }}$ \\
\hline
\end{tabular}

Values in the same column with the same superscript letters are statistically equal. Values represent the $\mathrm{Me} \pm$ $\mathrm{SEM} ; \mathrm{n}=3 ; \mathrm{p} \leq 0.05$, Tukey's test.

The acidity of the fresh cotyledon $(0 \mathrm{~h})$ was lowest with $\mathrm{SM}(0.58 \pm 0.00$ as acetic acid $\mathrm{g} / 100 \mathrm{~g}$ cocoa) and increased to a peak of $2.34 \pm 0.18$ after $120 \mathrm{~h}$ of fermentation; upon completion of fermentation (168 h), the acidity was $2.34 \pm 0.18$ as acetic acid $\mathrm{g} / 100 \mathrm{~g}$ cocoa. These results were similar to those reported an acidity level of 2.37 for fermented cocoa cotyledons. The total concentration of acids was significantly higher than all the other chemical groups. The total acids concentration increased significantly at the beginning of fermentation (2 and 4 days) (Rodriguez et al., 2012).

\subsection{Total polyphenol content in cocoa beans during fermentation}

The results showed statistically significant differences $(p \leq 0.05)$ in total polyphenol content between $\mathrm{M}$ and SM samples throughout fermentation (Figure 2). The highest total polyphenol content existed in fresh $(0 \mathrm{~h})$ cocoa beans ( 7.0 g GAE/100 $\mathrm{g}$ cocoa) with either M or SM. Niemenak et al. (2006) indicated that different polyphenol contents in cocoa clones are partly due to genetic characteristics (i.e., variety) and environmental variables, such as growth conditions, light intensity, humidity, temperature, fertilizer use, health, stress, etc.

Figure 2 shows that the total polyphenol content in cocoa beans decreased throughout the fermentation process, resulting in $5.88 \pm 0.56 \mathrm{~g}$ GAE $/ 100 \mathrm{~g}$ cocoa with SM and $5.05 \pm 0.02 \mathrm{~g} \mathrm{GAE} / 100$ $\mathrm{g}$ cocoa with $\mathrm{M}$ after $168 \mathrm{~h}$. These results were similar to those reported by Zapata $e t$ al. (2013) in fermented, dried Trinitario cocoa (5.02 g GAE/100 g cocoa), also showed a decrease in polyphenol content between fresh and fermented beans. Niemenak et al. (2006) suggested this decrease is due to the spread of polyphenols outside the cotyledon during fermentation. Othman et al. (2007) suggested that polyphenol content differs by bean variety, the degree of fermentation, and different processing parameters.

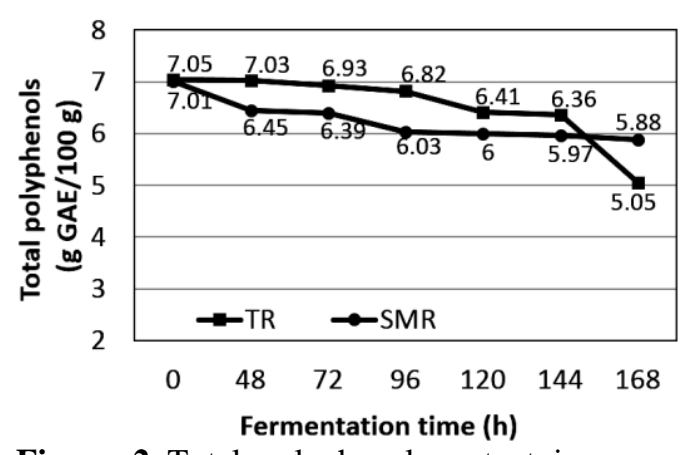

Figure 2. Total polyphenol content in cocoa beans during fermentation with manually (M) and semi-mechanized (SM) cocoa beans transfer.

\subsection{Anthocyanin content in cocoa beans during fermentation}

The results showed a statistically significant difference $(\mathrm{p} \leq 0.05)$ in anthocyanin content among $\mathrm{M}$ and SM samples throughout fermentation (Figure $3)$. Fresh cocoa beans $(0 \mathrm{~h})$ had the highest anthocyanin content with both SM and M $(15.59 \pm 0.44$ and $13.26 \pm 0.96 \mathrm{mg}$ cyanidin-3-glucoside/g cocoa, respectively). 


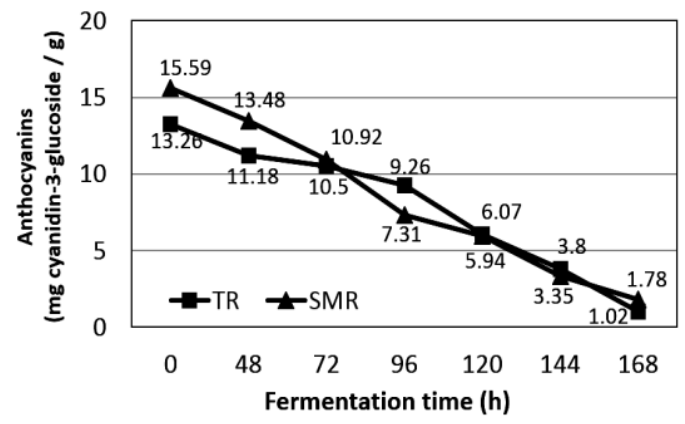

Figure 3. Anthocyanin content in cocoa beans during fermentation with manually $(\mathrm{M})$ and semi-mechanized (SM) cocoa beans transfer.

Niemenak et al. (2006) reported the average value of total anthocyanin in freshly harvested, fermented beans from nine cocoa genotypes were $6587.5,8239$ and $6720 \mathrm{mg} / \mathrm{kg}$ dry matter respectively, obviously lower than current results. The cotyledon staining is a typical genetic characteristic associated with the cocoa variety and can vary from white (Creole) to highly pigmented (Forastero), with different shades and color distributions. Exists procyanidin in various proportions depending on the cocoa cultivar, which explains the existing empirical associations between color intensity and bitterness/astringency of pigmented beans, as well as differences in anthocyanin content between studies.

Figure 3 shows a rapid decrease in total anthocyanin content with both $\mathrm{M}$ and SM, resulting in $1.78 \pm 0.71$ and $1.02 \pm 0.21 \mathrm{mg}$ cyanidin-3-glucoside/g cocoa, respectively, after $168 \mathrm{~h}$ of fermentation. These results were similar to those found by Zapata et al. (2013) who reported $1.05 \pm$ $0.045 \mathrm{mg}$ cyanidin-3-glucoside/g of fermented Trinitario cocoa beans. The Forastero and Criollo cocoa beans undergo changes in chemical components during fermentation, demonstrated that anthocyanins undergo enzymatic hydrolysis by the action of yeast during fermentation while some alkaloids and polyphenols are lost by oxidation. During fermentation, the anthocyanin content decreased by $92 \%$ with $\mathrm{M}$ and $88 \%$ with $\mathrm{SM}$ compared to fresh beans $(0 \mathrm{~h})$.

\subsection{Reducing sugar content in cocoa beans during fermentation}

Statistical analysis showed significant differences $(p \leq 0.05)$ in the reducing sugar content of cocoa beans during fermentation (Figure 4). The reducing sugar content was highest in fresh beans $(0 \mathrm{~h})$ with $\mathrm{M}$ $(3.83 \%)$ and SM (3.41\%). Both results were higher than those reported by Graziani et al. (2003) who found $3.39 \%$ reducing sugar content in fresh beans. These observed differences may be due to factors such as bean variety and maturity of fruit.

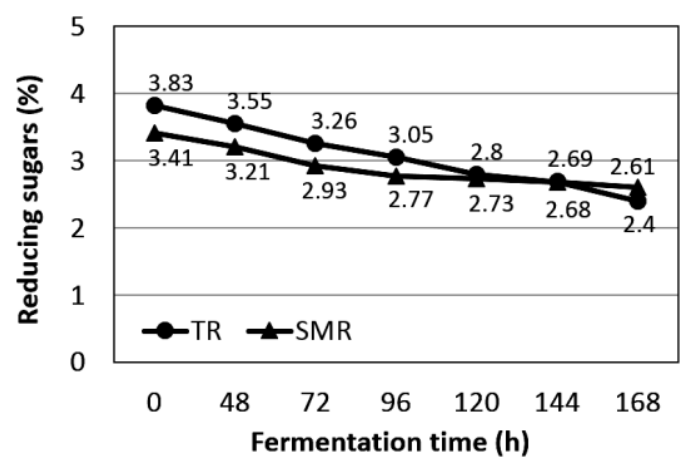

Figure 4. Reducing sugar content in cocoa beans during fermentation with manually (M) and semi-mechanized (SM) cocoa beans transfer.

The amount of reducing sugars decreased for both $\mathrm{M}$ and $\mathrm{SM}$ throughout cocoa beans fermentation process, with $2.61 \%$ remaining with $\mathrm{SM}$ and $2.40 \%$ with $\mathrm{M}$ after $168 \mathrm{~h}$ (Figure 4). Continuous chemical and biochemical changes occur during fermentation. For example, sugars are reduced by participating in no enzymatic browning reactions, which are favored by high temperatures (30-50 $\left.{ }^{\circ} \mathrm{C}\right)$. When drying proceeds slowly, the term water activity remains high for a longer period, which is optimal for Maillard chemistry (Cros y Jeanjean, 1995). Under these conditions, Maillard reactions thrive along with formation of the volatile fraction (Afoakawa, 2010).

\subsection{Theobromine content in cocoa beans during fermentation}

The results revealed statistically significant differences $(p \leq 0.05)$ in theobromine 
content throughout the process of fermentation for both types of systems (Fig. 5). The highest theobromine content was found in fresh beans $(0 \mathrm{~h})$ with both $\mathrm{SM}$ and $\mathrm{M}(7.78 \pm 0.23$ and $6.93 \pm 0.36 \mathrm{~g}$ theobromine/100 g cocoa, respectively).

At the end of the fermentation process $(168 \mathrm{~h})$, theobromine concentrations decreased to $5.78 \pm 0.19$ and $5.21 \pm 0.03 \mathrm{~g}$ theobromine/100 g cocoa with SM and M, respectively (Figure 5). Although Rodriguez et al. (2012) also reported a decrease after fermentation, the theobromine content $(2.93 \mathrm{~g}$ theobromine/100 $\mathrm{g}$ fermented beans) was much lower than found herein. It is known that during the post-harvest cacao pods, fermenting and drying cocoa beans decreases the content of theobromine while the chemical quality improves with the reduction of alkaloids and polyphenols, which impacts the organoleptic characteristics of cocoa (Rivera et al., 2012).

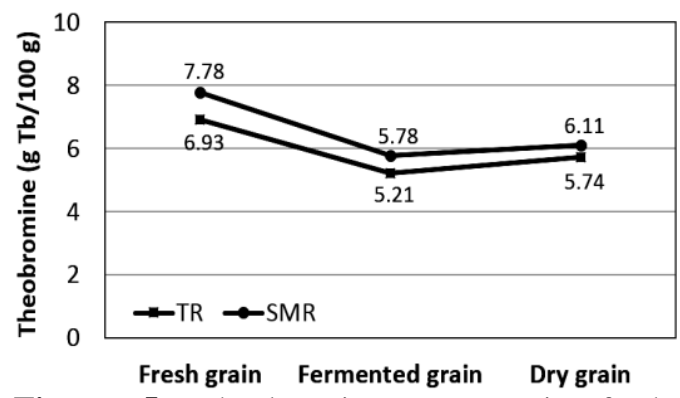

Figure 5. Theobromine content in fresh, fermented, and dried cocoa beans with manually (M) and semi-mechanized (SM) cocoa beans transfer.

\subsection{Caffeine content in cocoa beans during fermentation}

Statistical analysis revealed significant differences $(p \leq 0.05)$ in fresh, fermented, and dried cocoa beans with both types of cocoa beans transfer (Figure 6). A higher caffeine content was found in fresh cocoa beans and varied between $0.39 \pm 0.02$ and $0.51 \pm 0.02 \mathrm{~g}$ caffeine $/ 100 \mathrm{~g}$ cocoa with $\mathrm{SM}$ and $\mathrm{M}$, respectively. These results were similar to those reported by Nazaruddin et al. (2006) in fermented beans $(0.40 \mathrm{~g}$ caffeine/100 $\mathrm{g}$ cocoa). The decrease in alkaloid concentration is likely due to their diffusion out of the bean when the seed dies. Interestingly, the caffeine content with $\mathrm{M}$ and SM fell by $10.26 \%$ and $23.53 \%$ respectively, with fermentation.

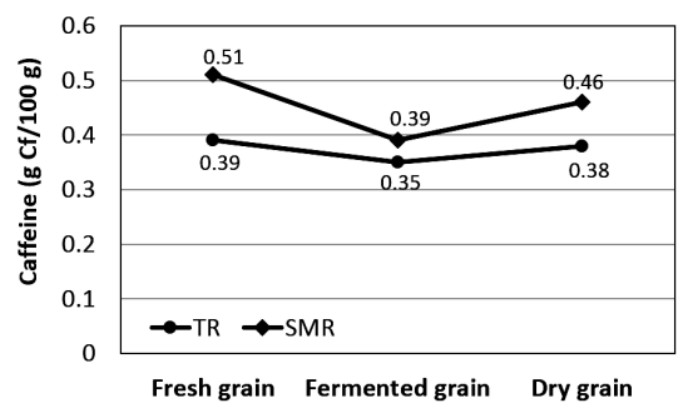

Figure 6. Variation of the caffeine content in fresh, fermented, and dried cocoa beans with manually (M) and semi-mechanized (SM) cocoa beans transfer.

\subsection{Ratio of theobromine to caffeine in fermented cocoa beans}

The ratio of theobromine:caffeine (Tb:Cf) with $\mathrm{M}$ and $\mathrm{SM}$ was 17.76 and 15.25 , respectively, which were higher than that reported by Zambrano et al. (2010). In this regard suggested a $\mathrm{Tb}: \mathrm{Cf}$ ratio $>8$ corresponds to the Foreigner variety; therefore, the Pachiza district of Peru has geographical areas that produce Foreigner cocoa.

\subsection{Percentage of fermentation in dried cocoa beans}

We found a significant difference ( $\mathrm{p} \leq$ 0.05 ) between the types of cocoa beans transfer used during the fermentation process (Table 4). The highest percentage of fermented beans was $91.67 \pm 0.78 \%$ with $\mathrm{SM}$ and $87.30 \pm 1.00 \%$ with $\mathrm{M}$. Furthermore, Alvarez et al. (2010) reported that a decrease in cocoa pulp acidity increases the proportion of brown beans. Development of brown pigments is an important stage during the drying process and is caused by the enzymatic oxidation of polyphenols, such as leucocyanidin and epicatechin, by polyphenol oxidase in the presence of oxygen and subsequent condensation of proteins (Ortiz de Bertorelli et al., 2009). 
Table 4

Percentage of fermentation in dried cocoa beans with manually and semi-mechanized cocoa beans transfer

\begin{tabular}{lc}
\hline $\begin{array}{l}\text { Cocoa beans } \\
\text { transfer }\end{array}$ & Fermentation $(\%)$ \\
\hline Manually & $87.30 \pm 1.00^{\mathrm{a}}$ \\
Semi-mechanized & $91.67 \pm 0.78^{\mathrm{b}^{*}}$ \\
\hline
\end{tabular}

Values with the same superscript letters are statistically equal. * significant. Values represent the $\mathrm{Me} \pm \mathrm{SEM}, \mathrm{n}=3, \mathrm{p} \leq 0.05$, Tukey's test.

\subsection{Time spent on manually (M) and semi-mechanized (SM) cocoa beans transfer}

The time taken to move cocoa beans was statistically different $(\mathrm{p} \leq 0.05)$ between $\mathrm{M}$ and SM samples (Figure 7). Cocoa beans transfer at $168 \mathrm{~h}$ of fermentation took the longest amount of time using either SM (18.21 $\mathrm{min})$ or $\mathrm{M}(17.22 \mathrm{~min})$. It is also important to note that the total removal time increased by adding the time spent moving beans to dryers. Overall, employees spent less time with SM (78.56 min) than M (96.24 min) of cocoa beans (Figure 7). During the fermentation process, beans undergo a series of biochemical changes, which favor SM. The time difference between cocoa beans transfer methods was $17.68 \mathrm{~min}$, this time difference between the methods is because the manual transfer of cocoa beans is done with more operator movements.

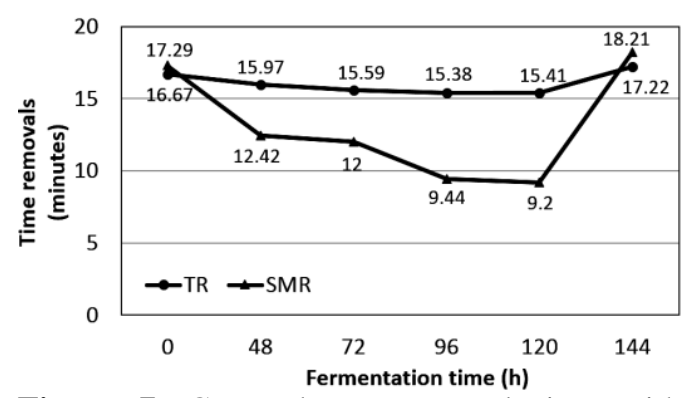

Figure 7. Cocoa beans removal time with manually (M) and semi-mechanized (SM) cocoa beans transfer.

\section{Conclusions}

Herein, the maximum fermentation temperature was $47.70 \pm 0.12{ }^{\circ} \mathrm{C}$ with $\mathrm{SM}$ and $47.70 \pm 0.15^{\circ} \mathrm{C}$ with $\mathrm{M}$ after $96 \mathrm{~h}$ of fermentation. The moisture content after $168 \mathrm{~h}$ of fermentation was $46.33 \pm 0.60 \%$ with $\mathrm{M}$ and $42.77 \pm 1.90 \%$ with SM. The cotyledon $\mathrm{pH}$ at the end of fermentation $(168 \mathrm{~h})$ was $4.76 \pm 0.03$ with $\mathrm{M}$ and 4.79 \pm 0.01 with $\mathrm{SM}$. The total titratable acidity was $2.88 \pm 0.18$ and $2.34 \pm 0.18$ as acetic acid (g/100 g cocoa), with $\mathrm{M}$ and SM, respectively. The highest total polyphenol content was $5.88 \pm 0.18 \mathrm{~g}$ it is also important to note that the total removal time increased after adding the time spent moving beans to dryers AGE/100 g fermented cocoa beans with SM, while the lowest was $5.05 \pm 0.02 \mathrm{~g}$ AGE/100 g cocoa with $M$. The highest anthocyanin content measured was $1.78 \pm 0.71 \mathrm{mg}$ cyanidin-3-glucoside/g fermented cocoa beans with SM, while the lowest was 1.02 $\pm 0.21 \mathrm{mg}$ cyanidin-3-glucoside/g cocoa with $M$. The highest reducing sugar content was found in fermented cocoa beans with SM $(2.61 \pm 0.02 \%)$, while the lowest was associated with M (2.40 \pm $0.16 \%)$. The theobromine content of dry beans was $5.74 \pm 0.02$ and $6.11 \pm 0.14 \mathrm{~g}$ theobromine/100 g cocoa with $\mathrm{M}$ and SM, respectively, while the caffeine content in dry beans was $0.38 \pm 0.01$ and $0.46 \pm 0.03$ $\mathrm{g}$ caffeine/100 g cocoa, respectively. The ratio of $\mathrm{Tb}: \mathrm{Cf}$ found suggests that the Pachiza district of Peru has Forastero cocoa plants growing in some areas. Overall, SM was found to produce the greatest amount of fermentation (91.67\%) and required the least amount of employee time to move beans $(78.56 \mathrm{~min})$.

\section{Acknowledgments}

The authors would like to thank Innovate Peru and the Ministry of Production of Peru for research funding.

\section{References}

Afoakwa, E.; Quao, J.; Takrama, J.; Budu, A.; Saalia, F.; 2011. Chemical composition and physical quality characteristics of Ghanaian cocoa beans as affected by pulp pre-conditioning and fermentation. Journal of Food Science and Technology 50(6): 1097-1105.

Afoakwa, E. 2010. Chocolate Science and Technology. John Wiley \& Sons Ltd. The Atrium, Southern Gate, Chichester, West Sussex, PO19 8SQ, United Kingdom. 
Afoakwa, E.; Paterson, A.; Fowler, M.; Ryan, A. 2008. Flavor Formation and Character in Cocoa and Chocolate: A Critical Review. Critical Reviews in Food Science and Nutrition 48(9): 840-857.

Alvarez, C.; Tovar, L.; García, H.; Morillo, F.; Sánchez, P.; Girón, C.; De Farias, A. 2010. Evaluation of the commercial quality of the cocoa bean (Theobroma cacao L.) using two types of fermenters. National Institute for Agricultural Research (INIA-Miranda). UDO Agricultural Science magazine 10.

Amores, F.; Palacios, A.; Jimenez, J.; Zhang, D. 2009. Environmental environment, genetics, and singling quality attributes of cocoa in the north east of the province of Esmeraldas. Technical Bulletin N 135. Ecuador. $119 \mathrm{p}$.

AOAC- 1995. Official Methods of Analysis, Methods 931.04, 942.15, 970.21 16th Edn., AOAC International, Arlington, VA.

Cros, E.; Jeanjean, N. 1995. Cocoa quality: effect of fermentation and drying. Plantations, recherché, developement 24: 25-27.

De Melo Pereira, G.; Magalhães, K.; de Almeida, E.; da Silva Coelho, I.; Schwan, R.F. 2013. Spontaneous cocoa bean fermentation carried out in a novel-design stainless steel tank: Influence on the dynamics of microbial populations and physical-chemical properties. International Journal of Food Microbiology 161(2): 121-133.

De Mendiburu, F. 2007. Agricolae: Statistical Procedures for Agricultural Research. Chapter 2. Available: http://tarwi.lamolina.edu.pe/ fmendiburu

Graziani de Fariñas, L.; Ortiz de Bertorelli, L.; Lemus, M.; Parra. 2002. Effect of mixing two types of grains cocoas on chemical characteristics during fermentation. Agronomía Tropical 52(3): 325-342.

Illeghems, K.; Weckx, S.; De Vuyst, L. 2015. Applying meta-pathway analyses through metagenomics to identify the functional properties of the major bacterial communities of a single spontaneous cocoa bean fermentation process sample. Food Microbiology 50: $54-63$.

Kongor, J.; Hinneh, M.; de Walle, D.; Afoakwa, E.; Boeckx, P.; Dewettinck, K. 2016. Factors influencing quality variation in cocoa (Theobroma cacao) bean flavour profile - A review. Food Research International 82: 44-52.

Lo Coco, F.; Lanuzza, F.; Micali, G.; Cappellano, G. 2007. Determination of Theobromine, Theophylline, and Caffeine in by-Products of Cupuacu and Cacao Seeds by High-Performance Liquid Chromatography. Journal of Chromatographic Science 45(5): 273-275.

Menguy, L.; Prim, D.; Carlin-Sinclair, A.; Marc, I. 2009. The Determination of Methylxanthines in Chocolate and Cocoa by Different Separation Techniques: HPLC, Instrumental TLC, and MECC. Journal of Chemical Education 86(11): 1307.

Miller, G. 1959. Use of Dinitrosalicylic Acid Reagent for Determination of Reducing Sugar. Anal. Chem. 31(3): 426-428.
National Federation of Cocoa - Cocoa National Fund. 2004. The benefit and physicochemical characteristics of cocoa (Theobroma cacao L.). Ministry of Agriculture and Rural Development - Colombia. Editorial Produmedios. pág. 8.

Nazaruddin, R.; Seng, L.; Hassan, O.; Said, M. 2006. Effect of pulp preconditioning on the content of polyphenols in cocoa beans (Theobroma Cacao) during fermentation. Industrial Crops and Products, 24(1): 87-94.

Niemenak, N.; Rohsius, C.; Elwers, S.; Omokolo Ndoumou, D.; Lieberei, R. 2006. Comparative study of different cocoa (Theobroma cacao L.) clones in terms of their phenolics and anthocyanins contents. Journal of Food Composition and Analysis 19(6-7): 612-619.

Ortiz de Bertorelli, L.; Graziani De Fariñas, L. Gervaise, L. 2009. Influence of various factors on characteristics of fermented cocoa beans and sun-dried. Agronomía Trop. 59(2): 119-127.

Othman, A.; Ismail, A.; Abdul-Ghani, N.; Adenan, I. 2007. Antioxidant capacity and phenolic content of cocoa beans. Food Chemistry 100(4): 1523-1530.

Rivera, M.F.; Guzmán-Cedeño, A.; Peña, M.; Medina, H.; Casanova, L.; Barrera, A.; Nivela, P. 2012. Effect of type and fermentation time on the physical and chemical quality of cocoa (Theobroma cacao L.) National type. Journal Ciencia y Tecnología 5(1): 712.

Rodriguez J.; Escalona, H.; Contreras, S.; Orozco, I.; Jaramillo, E.; Lugo, E. 2012. Effect of fermentation time and drying temperature on volatile compounds in cocoa. Food Chemistry 132(1): 277-288.

Sandhya, M.; Yallappa, B.; Varadaraj, M.; Puranaik, J.; Rao, L.; Janardhan, P.; Murthy, P. 2016. Inoculum of the starter consortia and interactive metabolic process in enhancing quality of cocoa bean (Theobroma cacao) fermentation. LWT - Food Science and Technology 65: 731-738.

Schwan R. 1998. Cocoa Fermentations Conducted with a Defined Microbial Cocktail Inoculum. Applied and Environmental Microbiology 64(4): 1477-1483.

Sultana, B.; Hussain, Z.; Asif, M.; Munir, A. 2012. Investigation on the Antioxidant Activity of Leaves, Peels, Stems Bark, and Kernel of Mango (Mangifera indica L.). Journal of Food Science 77(8): C849-C852.

Symonowicz, M.; Sykuła-Zajac, A.; Łodyga-Chruścińska, E.; Rumora, I.; Straukas, M. 2012. Evaluation of polyphenols and anthocyanins contents in black chockeberry--Photinia melanocarpa (Michx.) fruits extract. Acta Pol Pharm. 69(3): 381-387.

Zambrano, A.; Romero, C.; Gomez, A. 2010. Chemical precursors evaluation of aroma and flavor of Criollo cocoa merideño during fermentation two soil and climate conditions. Venezuela. Trop. 60(2): 211-219.

Zapata, S.; Tamayo, A.; Alberto, B. 2013. Effect of fermentation on Colombian antioxidant activity of different cacao clones. Rev Cubana Plant Med 18(3): 391-404. 